\title{
Mowa pacjentki z chorobą Parkinsona w fazie zaawansowanej
}

\begin{abstract}
Mateusz Szurek, Mowa pacjentki z choroba Parkinsona w fazie zaawansowanej [Speech disorders of patient suffering from advanced Parkinson's disease]. Interdyscyplinarne Konteksty Pedagogiki Specjalnej, nr 14, Poznań 2016. Pp. 137-157. Adam Mickiewicz University Press. ISSN 2300-391X

The purpose of this article is to present speech disorders of 91 years old patient suffering from advanced Parkinson's disease (it is the last stage of the disease when all symptoms are stronger) and to draw attention to the need of mentioning the impact of speech therapy while describing the disease. In the article an author is introducing the patient and her current condition. Mainly it is focused on the speech therapy diagnosis that was based on particular aspects of speech (such as: general condition of the patient, phonation, comprehension of speech and naming, repeating, dialogues and storytelling, reading, counting and writing). In the final part, the effectiveness of speech therapy is presented. This publication might become a leading example for other speech therapist on how to manage the therapy for people suffering from these types of disorders in speaking and communication.
\end{abstract}

KEY WORDS: Parkinson's disease, speech disorder, dysarthria

\section{Wprowadzenie}

Starość to ostatni okres życia człowieka, z którym wiążą się zmiany funkcjonowania poznawczego, emocjonalnego, społecznego, a także biologicznego. Pogorszenie stanu fizjologicznego niesie 
ze sobą ryzyko wystąpienia wielu chorób. Jednym ze schorzeń, które może dotknąć osobę w wieku starczym, jest choroba Parkinsona.

Wiedza na temat tego schorzenia jest coraz większa. Zdobywanie nowych doświadczeń pozwala na opracowywanie innowacyjnych sposobów pracy z pacjentem. Praktyką stało się zwracanie uwagi na mowę i komunikację chorego. Choroba Parkinsona jest jednym ze schorzeń neurodegradacyjnych związanym z występowaniem zaburzeń mowy ${ }^{1}$. W związku z tym w momencie pojawienia się pierwszych objawów należy wdrożyć postępowanie logopedyczne, które jest niezbędne do utrzymania sprawności mówienia i komunikacji. Intensywność ćwiczeń natomiast przyczynia się do spowolnienia progresji choroby.

\section{Choroba Parkinsona - ujęcie teoretyczne}

Choroba Parkinsona jest jedną z najczęstszych chorób zwyrodnieniowych układu nerwowego ${ }^{2}$. To postępujące schorzenie neurologiczne, którego głównymi symptomami są drżenie występujące w spoczynku, sztywność mięśni oraz bradykinezja (są to objawy tzw. triady parkinsonowskiej) ${ }^{3}$. Choć leczenie wielu chorób zwyrodnieniowych układu nerwowego jest najczęściej nieskuteczne bądź przynosi niezadowalające efekty, właściwa terapia w chorobie Parkinsona pozwala na normalne funkcjonowanie przez wiele lat

${ }^{1}$ M. Rudzińska, I. Gatkowska, E. Mirek, A. Szczudlik, Choroba Parkinsona. Poradnik dla pacjentów i ich rodzin, Wydawnictwo Uniwersytetu Jagiellońskiego, Kraków 2009, s. 51.

2 Częstość występowania parkinsonizmu w różnych krajach wynosi 100-200 przypadków na 100 tys. osób populacji ogólnej (w tym 85\% to przypadki choroby Parkinsona, natomiast $15 \%$ to inne zespoły parkinsonowskie). W Polsce obecnie żyje ok. 50-60 tys. chorych. Szacuje się, że na chorobę Parkinsona zapada 10-20 osób na 100 tys. osób populacji ogólnej. Rocznie rozpoznawanych jest ok. 4000-6000 nowych przypadków parkinsonizmu (W. Kuran, Żyję z choroba Parkinsona, Wydawnictwo Lekarskie PZWL, Warszawa 2002, s. 16).

${ }^{3}$ B. McCall, Jak radzić sobie $z$ choroba Parkinsona?, Wydawnictwo Feeria, Łódź 2007, s. 12. 
od zdiagnozowania choroby. Zanik istoty czarnej zlokalizowanej w śródmózgowiu, odpowiedzialnej za produkcję dopaminy, przyczynia się do wystąpienia objawów choroby Parkinsona. Produkcja dopaminy zmniejsza się wraz z wiekiem także u osób zdrowych, jednak za objaw choroby przyjmuje się obniżenie jej produkcji do $20 \%$. Choć wiadomo, że choroba Parkinsona jest wynikiem niedoboru dopaminy $\mathrm{w}$ mózgu, to mimo tego nie wskazano dotychczas dokładnej przyczyny tego schorzenia. W diagnozowaniu choroby i poszukiwaniu jej przyczyn naukowcy uwzględniają takie kwestie jak: starzenie się, czynniki genetyczne, czynniki środowiskowe, wirusy czy urazy głowy 5 .

\section{Objawy kliniczne}

Choroba Parkinsona pojawia się najczęściej między 50. a 60. rokiem życia. Średni wiek zachorowania szacuje się na 58 lat. Początkowo schorzenie to rozwija się potajemnie i objawia osłabieniem mięśni oraz bólami. W późniejszym okresie zaczynają być widoczne zaburzenia mowy oraz zasadnicze objawy, czyli drżenie, sztywność i powłóczenie nogami. Ponieważ schorzenie to pojawia się w wieku podeszłym, często zdarza się, że proces starzenia się maskuje obraz rozwijającej się choroby. Należy więc skonsultować pierwsze objawy z doświadczonym neurologiem, który potrafi odróżnić naturalne oznaki zmniejszania się sprawności ruchowej od choroby Parkinsona ${ }^{6}$.

W związku z tym, że nie istnieje żaden test diagnostyczny choroby Parkinsona, rozpoznawana jest ona na podstawie wystąpienia

${ }^{4}$ A. Gajos, Co to jest choroba Parkinsona, jak często występuje i jakie sa kryteria rozpoznania?, [w:] Mam chorobę Parkinsona. Poradnik dla chorych i ich rodzin, red. J. Sławek, Wydawnictwo Via Medica, Gdańsk 2010, s. 1-2.

${ }^{5}$ Dokładny opis przyczyn choroby Parkinsona można znaleźć w publikacji B. McCall Jak radzić sobie z chorobq Parkinsona?, Wydawnictwo Feeria, Łódź 2007, s. $21-26$.

${ }^{6}$ K. Gawęda, J. Łazewski, Rehabilitacja mowy w chorobie Parkinsona, Wydawnictwo Mada, Warszawa 2012, s. 9. 
i narastania objawów klinicznych ${ }^{7}$. Choroba ta diagnozowana jest wtedy, gdy występują dwa spośród trzech objawów tzw. triady parkinsonowskiej. Dodatkowo u pacjenta pojawia się jednostronny początek symptomów, który jest jednoznaczną oznaką choroby przy nakładających się objawach towarzyszących ${ }^{8}$.

\section{Stadia choroby}

Choroba Parkinsona jest schorzeniem postępującym - każdego roku stan pacjenta pogarsza się, nasilają się występujące objawy i pojawiają nowe. Postęp choroby zależy najczęściej od czasu zachorowania. Jeśli wystąpiła ona przed 50. rokiem życia, rozwija się wolniej9. Rozwój schorzenia można podzielić na okresy, które zostały przedstawione $\mathrm{w}$ tabeli 1.

Tabela 1. Stadia rozwoju choroby Parkinsona (na podst.: P. Janik, Przebieg choroby $i$ jej rokowanie [w:] Mam chorobe Parkinsona. Poradnik dla chorych $i$ ich rodzin, red. J. Sławek, Wydawnictwo Via Medica, Gdańsk 2010, s. 51-55)

\begin{tabular}{|l|l|}
\hline & - brak objawów ruchowych typowych dla choroby, tj. drżenia \\
& ręki, usztywnienia mięśni, spowolnienia ruchów \\
- upośledzenie węchu & - gwałtowne ruchy ciała i kończyn w czasie snu \\
Okres przed- & - ból barku lub nogi \\
kliniczny & -zaparcia \\
- obniżenie nastroju & - diagnoza może być postawiona wyłącznie na podstawie badań \\
& dodatkowych, które przeprowadza się w tym okresie tylko \\
& u osób z grupy wysokiego ryzyka (są to osoby, u których wy- \\
stępowała choroba w rodzinie)
\end{tabular}

${ }^{7}$ O. Jauer-Niworowska, Zaburzenia mowy u osób z chorobą Parkinsona - nie tylko dyzartria. Złożoność uwarunkowań trudności w komunikacji werbalnej, Wydział Polonistyki Uniwersytetu Warszawskiego, Warszawa 2016, s. 39.

${ }^{8}$ H. Petit, H. Allain, P. Vermersch, Choroba Parkinsona. Klinika i leczenie, Wydawnictwo Medyczne Sanmedica, Warszawa 1997, s. 28.

${ }^{9}$ P. Janik, Przebieg choroby i jej rokowanie [w:] Mam chorobę Parkinsona. Poradnik dla chorych $i$ ich rodzin, red. J. Sławek, Wydawnictwo Via Medica, Gdańsk 2010, s. 51. 
cd. tab. 1

\begin{tabular}{|c|c|}
\hline Okres wczesny & $\begin{array}{l}\text { - występowanie objawów ruchowych: drżenia, spowolnienie } \\
\text { ruchów, sztywność mięśni } \\
\text { - objawy nie utrudniają normalnego funkcjonowania } \\
\text { - dobra reakcja na farmakoterapię (wycofywanie się, zmniejszenie } \\
\text { objawów ruchowych) } \\
\text { - chory nadal w pełni sprawny }\end{array}$ \\
\hline & $\begin{array}{l}\text { - wystąpienie nasilonych objawów po jednej stronie ciała } \\
\text { - narastające spowolnienie ruchowe } \\
\text { - trudności w poruszaniu się (nagłe zatrzymywanie się, zmiany } \\
\text { kierunku, niemożność wykonania pierwszego kroku) } \\
\text { - problemy z obracaniem się na łóżku z boku na bok oraz ze } \\
\text { wstawianiem z łóżka } \\
\text { - dysfagia } \\
\text { - zaburzenia mowy } \\
\text { - zaburzenia równowagi } \\
\text { - zmiany osobowości } \\
\text { - reakcja na farmakoterapię jest nadal zadowalająca (po zwięk- } \\
\text { szeniu dawki leków) } \\
\text { - chory jest nadal niezależny bądź potrzebuje nieznacznej pomo- } \\
\text { cy od osób trzecich }\end{array}$ \\
\hline $\begin{array}{l}\text { Okres późny } \\
\text { (zaawansowa- } \\
\text { ny) }\end{array}$ & $\begin{array}{l}\text { - wystąpienie powyższych objawów, a dodatkowo: } \\
\text { - farmakoterapia nie przynosi już zadowalających efektów } \\
\text { - pojawienie się fluktuacji i dyskinezy } \\
\text { - nagłe lub przypadkowe epizody pogorszenia się sprawności } \\
\text { ruchowej } \\
\text { - zespół przełączenia (pojawianie się na przemian okresów dobrej } \\
\text { sprawności i pełnej niesprawności) } \\
\text { - częste zmiany nastrojów } \\
\text { - spowolnienie myślenia } \\
\text { - wystąpienie objawów bólowych, mrowienia kończyn, duszności } \\
\text { - wystąpienie objawu przymrużenia (częściowa niemożność } \\
\text { wykonania dowolnego ruchu) } \\
\text { - chory jest uzależniony od osób trzecich, wymaga pomocy } \\
\text { w codziennym życiu } \\
\text { - pogorszenie się funkcji poznawczych }\end{array}$ \\
\hline
\end{tabular}




\section{Zaburzenia mowy w chorobie Parkinsona}

Objawy zaburzeń mowy pojawiają się zazwyczaj w stadium średniozaawansowanym. Oznacza to, że przez długi okres trwania choroby mowa jest prawidłowa ${ }^{10}$. Niekiedy trudno jest orzec, czy pojawiające się zaburzenia głosu spowodowane są chorobą, czy może naturalnym starzeniem się organizmu. Wiek podeszły przyczynia się do fizjologicznego upośledzenia słuchu w wyniku czego dochodzi do zmiany barwy głosu - staje się on wówczas osłabiony i zaczyna drżeć, a jego skala zwęża się. Za objawy zaburzenia głosu i mowy, które świadczą o podłożu chorobowym, można uznać m.in.:

- ściszenie głosu,

- powolną, monotonną i przerywaną mowę,

- zubożenie mimiki,

- ślinienie się,

- mowę bezbarwną i zamazaną artykulację,

- pozbawioną ruchów mimicznych, maskowatą twarz,

- niedostateczną koordynację zwiotczałych lub zbyt napiętych mięśni nasady,

- czasem przyśpieszenie tempa mówienia w końcowej części wypowiedzi, które utrudnia zrozumienie chorego ${ }^{11}$.

Rozumienie mowy najczęściej zostaje zachowane. Chorzy w mowie spontanicznej zaczynają przekazywać mniej informacji, mają także coraz większe trudności w konstruowaniu zdań. Nie są one jednak związane z utratą słownictwa, a jedynie z nieprawidłowym posługiwania się słowami12.

\section{Opis pacjentki - studium indywidualnego przypadku}

Pacjentka ma 91 lat. Chorobę Parkinsona zdiagnozował u niej neurolog 10 lat temu. Kobieta całe życie zajmowała się domem, pra-

\footnotetext{
${ }^{10}$ H. Petit, H. Allain, P. Vermersch, op. cit., s. 34.

${ }^{11}$ K. Gawęda, J. Łazewski, op. cit., s. 45.

12 H. Petit, H. Allain, P. Vermersch, op. cit., s. 39.
} 
cowała na roli. Chorobę Parkinsona wykryto u niej przypadkowo, podczas leczenia innych schorzeń neurologicznych - wystąpiły bowiem objawy sztywności i drżenia lewej ręki. Symptomy choroby pojawiły się tylko po jednej stronie, co było jedną z podstaw do postawienia diagnozy. Po rozpoczęciu farmakoterapii pacjentka poczuła się znacznie lepiej. Leki spowodowały ustąpienie drżenia i polepszenie samopoczucia. Z roku na rok symptomy zaczęły się nasilać, mimo przyjmowanych leków.

\section{Stan pacjentki}

Obecnie pacjentka znajduje się w późnym stadium choroby. Specjalista neurolog stosuje leczenie farmakologiczne w zwiększonej dawce. Na podstawie Mapy Dobrostanu w chorobie Parkinsona ${ }^{13}$ oceniono u pacjentki stan zaburzeń: snu, nastroju, pamięci, koncentracji uwagi, układu pokarmowego, ruchu, inne zaburzenia pozaruchowe oraz nasilenie bólu. Dane pozyskano z wywiadu z chorą. Aktualny stan pacjentki został przedstawiony w tabeli 2.

Tabela 2. Stan pacjentki (opracowanie własne)

\begin{tabular}{|l|l|}
\hline Zaburzenia ruchu & $\begin{array}{l}\text { Pacjentka ma problemy z rozpoczęciem ruchu. Rano czuje } \\
\text { sztywność mięśni nóg. Występują u niej drżenia, a ruchy } \\
\text { są spowolnione. Obecne są niekontrolowane ruchy (dyski- } \\
\text { nezy), zaburzenia równowagi. Chora pochylona jest do } \\
\text { przodu, ruchy rąk są ograniczone, co przejawia się między } \\
\text { innymi w motoryce małej, tj. w piśmie - jest ono małe } \\
\text { (występuje mikrografia) }\end{array}$ \\
\hline Zaburzenia snu & $\begin{array}{l}\text { Chora budzi się w nocy. Od rana do wieczora czuje się } \\
\text { zmęczona. Występują napady senności w ciągu dnia }\end{array}$ \\
\hline Zaburzenia nastroju & $\begin{array}{l}\text { Pacjentka zdaje sobie sprawę z choroby. Nie cieszą ją już } \\
\text { rzeczy, które sprawiały jej wcześniej radość. Czuje się } \\
\text { nieszczęśliwa, traci chęci do życia }\end{array}$ \\
\hline
\end{tabular}

${ }^{13}$ http://www.ucb.pl/_up/ucb_pl/documents/PL\%20LPSRC\%20ROT\%20053 \%202013\%2011\%20-\%20mapa \%20dobrostanu \%20-\%20wersja \%20ostateczna.pdf [dostęp: 1.03.2016]. 
cd. tab. 2

\begin{tabular}{|l|l|}
\hline $\begin{array}{l}\text { Zaburzenia pamięci } \\
\text { i koncentracji uwagi }\end{array}$ & $\begin{array}{l}\text { Chora zdaje sobie sprawę z tego, że często zapomina bie- } \\
\text { żących myśli. Ma problemy z koncentracją. Mówi powoli. } \\
\text { Zaburzona jest pamięć krótkotrwała }\end{array}$ \\
\hline $\begin{array}{l}\text { Problemy układu po- } \\
\text { karmowego }\end{array}$ & $\begin{array}{l}\text { Pacjentka ma problemy z połykaniem (dysfagia), występu- } \\
\text { je ślinotok, nieraz ma nudności i wymioty oraz zaparcia }\end{array}$ \\
\hline $\begin{array}{l}\text { Inne zaburzenia poza- } \\
\text { ruchowe }\end{array}$ & $\begin{array}{l}\text { W wywiadzie pacjentka zgłasza zawroty głowy podczas } \\
\text { podnoszenia się z łóżka. Zauważa zmiany w węchu, smak } \\
\text { nie jest zaburzony w znacznym stopniu. Nadmiernie się } \\
\text { poci. Obserwuje się także zmiany masy ciała, które nie są } \\
\text { związane z dietą }\end{array}$ \\
\hline Ból & $\begin{array}{l}\text { Chora odczuwa ból zarówno w dzień, jak i w nocy. Przez } \\
\text { cały czas występują u niej bolesne sztywności oraz skurcze } \\
\text { stóp, dłoni, kostek nadgarstków, a coraz częściej silne bóle } \\
\text { głowy }\end{array}$ \\
\hline
\end{tabular}

\section{Diagnoza logopedyczna}

Diagnoza logopedyczna została przeprowadzona na podstawie Kwestionariusza diagnostycznego zaburzeń mowy ze szczególnym uwzględnieniem afazji i dysartrii dla młodzieży i dorostych z $2014 \mathrm{r}$. autorstwa Katarzyny Szłapy, Iwony Tomasik i Sławomira Wrzesińskiego. Składała się z następujących części:

1. Badanie ogólnego stanu komunikacji.

2. Badanie mowy zautomatyzowanej.

3. Badanie gnozji słuchowej.

4. Badanie sprawności aparatu artykulacyjnego.

5. Badanie fonacji.

6. Badanie rozumienia mowy.

7. Badanie powtarzania.

8. Badanie nazywania.

9. Badanie mowy czynnej.

10. Badanie mowy czynnej - opowieściowej.

11. Badanie czytania.

12. Badanie liczenia.

13. Badanie pisania. 


\section{Badanie ogólnego poziomu komunikacji pacjentki}

Głos pacjentki znacznie różni się od tego, który miała przed wystąpieniem choroby - znacząco się ściszył oraz ochrypł. Tempo mowy jest zwolnione - pacjentka wolno artykułuje dźwięki. Wielokrotnie zastanawia się, co chce powiedzieć, przez co płynność jej mowy zaburzają częste pauzy. Ekspresja mowy zubożała, występują dodatkowo zaburzenia dykcji. Pacjentka nie potrafi głośno mówić ani krzyczeć. Trudność sprawia jej również śpiewanie. Prozodia także została zaburzona - mowa stała się monotonna, brak w niej akcentowania, melodii i rytmu. Podczas artykulacji, która jest zamazana, zdarzają się elizje i substytucje (nie występują one jednak często). Niekiedy pacjentce sprawia trudność układanie złożonych konstrukcji składniowych. Na jej twarzy nadal widoczne są ruchy mimiczne. Występuje nieznaczny ślinotok. Zaburzenia obserwuje się na poziomie oddechu, fonacji i artykulacji, dlatego stwierdza się występowanie u pacjentki zaburzeń mowy o podłożu dyzartrycznym.

\section{Badanie mowy zautomatyzowanej}

Chora została poproszona o wymienienie kolejno: liczb od 1 do 10, nazw dni tygodnia, nazw pór roku, nazw miesięcy. Każdą z tych czynności wykonała poprawnie. Świadczy to o tym, że mowa zautomatyzowana pozostaje $\mathrm{w}$ normie.

\section{Badanie gnozji słuchowej}

Zadaniem pacjentki było rozpoznanie zaprezentowanego dźwięku: chrobotania kluczy, szczekania psa, silnika samochodu, grającej gitary. Zidentyfikowała ona wszystkie dźwięki po zwiększeniu głośności, ponieważ $w$ naturalnym natężeniu były dla niej zbyt ciche. Ubytek słuchu jest jednak stanem fizjologicznym, wynikającym z podeszłego wieku. 


\section{Badanie sprawności aparatu artykulacyjnego}

Badanie to ukazało ograniczenia $\mathrm{w}$ sprawności narządów artykulacyjnych. Pacjentka miała problemy przede wszystkim z rozchyleniem żuchwy. Ruchy języka były także ograniczone, jednak chora poradziła sobie z opuszczaniem języka na brodę, unoszeniem języka w kierunku nosa, do podniebienia, wypychaniem policzków językiem, wysuwaniem języka szerokiego i wąskiego. Nie były to jednak ruchy precyzyjne. Ściąganie i rozciąganie warg nie stanowiło problemu. Pacjentka nie potrafiła zakryć jedynie wargi górnej dolnymi zębami. Powyższe problemy pokazują, że chora zmaga się z wzmożonym napięciem mięśni twarzy, które jest charakterystyczne dla choroby Parkinsona.

\section{Badanie fonacji}

Badanie fonacji polegało na wymawianiu samogłoski $a$ podczas pełnego wydechu. Poproszono pacjentkę, aby trzykrotnie wykonała zadanie. Średni czas fonacji samogłoski wyniósł 9 sekund, podczas gdy osoby ze zdrowym narządem głosu osiągają czas fonowania powyżej 20 sekund. Pacjentka ma o ponad połowę skróconą fonację, jej faza wydechowa jest bardzo krótka. Przyczynia się to do występowania trudności w operowaniu dłuższymi frazami podczas wypowiedzi, w wyniku których powstają częste przerwy w mówieniu w celu pobrania powietrza do płuc.

\section{Badanie rozumienia mowy i nazywania}

Badanie rozumienia mowy i nazywania składało się z dziewięciu części i dotyczyło:
a) części ciała na schemacie,
b) prostych i złożonych poleceń,
c) nazw rzeczowników,
d) nazw czynności, 
e) nazw przymiotników,

f) nazw przysłówków,

g) nazw liczebników,

h) nazw przyimków przestrzennych,

i) badania poprawności językowej.

Nie zauważono żadnych trudności we wskazywaniu części ciała na schemacie. Proste i złożone polecenia także nie sprawiały badanej problemu. Wykonywała je sprawnie, bez żadnych pomyłek. Niekiedy zastanawiała się przed wykonaniem ruchu, jednak zazwyczaj nie trwało to dłużej niż 4 sekundy. Wskazała także poprawnie wszystkie rzeczowniki, czasowniki, przymiotniki, przysłówki, liczebniki, przyimki przestrzenne. Rozumienie mowy zostało więc w pełni zachowane.

Pacjentka nie ma trudności z nazywaniem. W dwóch przypadkach użyła wyrażeń synonimicznych, tj. na telefon komórkowy i kaloryfer - odpowiednio nazywając je komórką i grzejnikiem. Przy obrazku komputera użyła początkowo nazwy komórka, jednak po chwili poprawiła się i nazwała przedmiot poprawnie. Podczas nazywania czynności, pacjentka użyła określenia na komputer patrzy przy obrazku, na którym chłopiec grał w gry komputerowe. Powyższe pomyłki, jeśli w ogóle można je takowymi nazwać, nie są częste i nie wpływają w żaden sposób na zaburzenia komunikacji.

W czasie badania poprawności językowej pacjentka miała za zadanie odnaleźć błędy gramatyczne w czytanych przez terapeutę zdaniach. Wszystkie wskazała prawidłowo i właściwie je poprawiła

\section{Badanie powtarzania}

Badanie powtarzania składało się z trzech części i dotyczyło kolejno:

a) powtarzania samogłosek, spółgłosek, sylab, rzeczowników i czasowników,

b) powtarzania grup słów,

c) powtarzania zdań. 
Pierwsza część badania została wykonana bezbłędnie. Przy powtarzaniu grup słów chora była w stanie powtórzyć ciąg trzech wyrazów jedno- i dwusylabowych. Wyrazy wielowyrazowe w ciągu sprawiły chorej trudność. Nie potrafiła kolejno odtworzyć ciągu słów sukienka, komputer, mikrofalówka z pamięci. Przypomniała sobie jednak wszystkie wyrazy, ale w niewłaściwej kolejności. Powyższe trudności świadczą o zaburzeniach pamięci krótkotrwałej. Powtórzenie krótkich i dłuższych zdań nie stanowiło dla pacjentki problemu.

\section{Badanie mowy czynnej - dialogowej}

Pacjentka chętnie rozmawia z innymi. Ciągle pozostaje osobą kontaktową, często lubi wspominać dawne czasy. Podczas badania mowy czynnej - dialogowej terapeuta trzymał przed sobą ilustrację, na której znajdowali się ludzie grillujący w ogrodzie - i kierował pytania do chorej. Jej zadaniem było udzielenie na nie odpowiedzi.

Chora poprawnie wykonywała polecenia terapeuty, wskazując i nazywając postacie oraz przedmioty znajdujące się na ilustracji. Nie miała także problemu z określeniem koloru poszczególnych elementów obrazka. Na pytanie: Co robią ludzie na ilustracji? odpowiedziała:

No tu jest mężczyzna. Będzie pędzit kiełbase nad grillem. Jest też dziewczynka i pani jakaś. Psa też widzę, piłkę ma w pysku. No i tyle.

Odpowiedzi udzielone przez pacjentkę były zgodne z sytuacją przedstawioną na obrazku.

\section{Badanie mowy czynnej - opowieściowej}

Zadanie pacjentki polegało na opisaniu tego, co widzi na przedstawionej ilustracji. Badana w następujący sposób opowiedziała sytuację dziejącą się na obrazku: 
No tu jest morze albo ocean jakiś, czy może statek, czy to okręt, to nie wiem, bo przecież się nie znam na tym. A tu siedza na plaży wczasowicze jakieś. A to nie wiem co to jest, jakieś białe takie. A to parasol jest. A tu smaruje ja tam jakiś facet, te panią. Co robi? Tam się kapie, tam stoi też. No i tu jest plaża. To jest nad morzem.

Chora opisywała obrazek w sposób chaotyczny. Nazywała poszczególne części ilustracji na przemian - raz po prawej stronie, raz po lewej. Choć brak w wypowiedzi charakterystycznych fraz typu: $w$ tle, z przodu, po lewej stronie, po prawej itp. oraz kolejności w opisywaniu ilustracji, przekaz był jasny i sformułowany poprawnie. Wszystkie charakterystyczne elementy zostały zauważone przez pacjentkę.

\section{Badanie czytania}

Badanie składało się z pięciu części, w skład których wchodziło czytanie:
a) liter,
b) sylab,
c) wyrazów,
d) zdań,
e) opowiadania.

W ostatniej części zbadano umiejętność czytania ze zrozumieniem pacjentce zostały zadane pytania po przeczytaniu fragmentu tekstu.

Chora, pomimo podeszłego wieku, nadal czyta bez okularów. Nie widzi jedynie małych liter, większe odczytuje poprawnie. Czytanie liter, sylab, wyrazów, zdań i opowiadania nie sprawiło jej trudności.

Sprawność czytania ze zrozumieniem plasuje się na niższym poziomie. Badana po przeczytaniu na głos tekstu, nie udzieliła odpowiedzi na pytania do niego. Nie pamiętała, co przeczytała. Jednak po odczytaniu tekstu po raz drugi poradziła sobie zdecydowanie lepiej. Udało jej się odpowiedzieć poprawnie na większość pytań. Zgłasza ona niejednokrotnie, że zapomina, co się do niej 
mówiło i prosi o przypomnienie. Świadczy to o zaburzeniu u pacjentki pamięci świeżej. Jak podkreślają Henri Petit, Herve Allain, Patrick Vermersch w swojej publikacji, u osób z tym schorzeniem pamięć świeża jest znaczniej zaburzona od pamięci dawnej, dlatego problem stanowi dla pacjentów nagłe przypominanie sobie określonych rzeczy ${ }^{14}$.

\section{Badanie liczenia}

Badanie to składało się z dwóch części i dotyczyło:

a) rozumienia nazw liczb i znaków matematycznych,

b) wyboru prawidłowego wyniku, liczenia w pamięci, obliczania zadań $\mathrm{z}$ treścią $\mathrm{w}$ pamięci.

Nie odnotowano żadnych problemów z wykonywaniem zadań matematycznych oraz $\mathrm{z}$ rozumieniem pojęć matematycznych. Pacjentka bardzo sprawnie i bezbłędnie wykonywała polecenia, nie musiała się dłużej zastanawiać.

\section{Badanie pisania}

Próba ta dotyczyła pisania z pamięci oraz przepisywania liczb, znaków matematycznych, swojego imienia, liter, sylab, słów oraz zdań. Dodatkowo pacjentka została poproszona także o napisanie dowolnego krótkiego tekstu.

W piśmie badanej widać lekkie objawy mikrografii, polegającej na zmniejszaniu liter i cyfr $\mathrm{w}$ trakcie pisania (nie jest ona jednak wzmożona). Kształt pisma jest zaburzony w wyniku drżenia ręki, ponieważ $u$ pacjentki jest ono znacznie nasilone. Chora ma problemy z pisaniem, szybko się męczy mimo wolnego tempa pisania. $\mathrm{Z}$ powodu trudności badana zaprzestała czynności pisania, nie rozwiązuje obecnie nawet krzyżówek, gdyż podczas długotrwałego trzymania długopisu boli ją ręka. Próbki pisma chorej zostały przedstawione poniżej.

${ }^{14}$ H. Petit, H. Allain, P. Vermersch, op. cit., s. 20. 


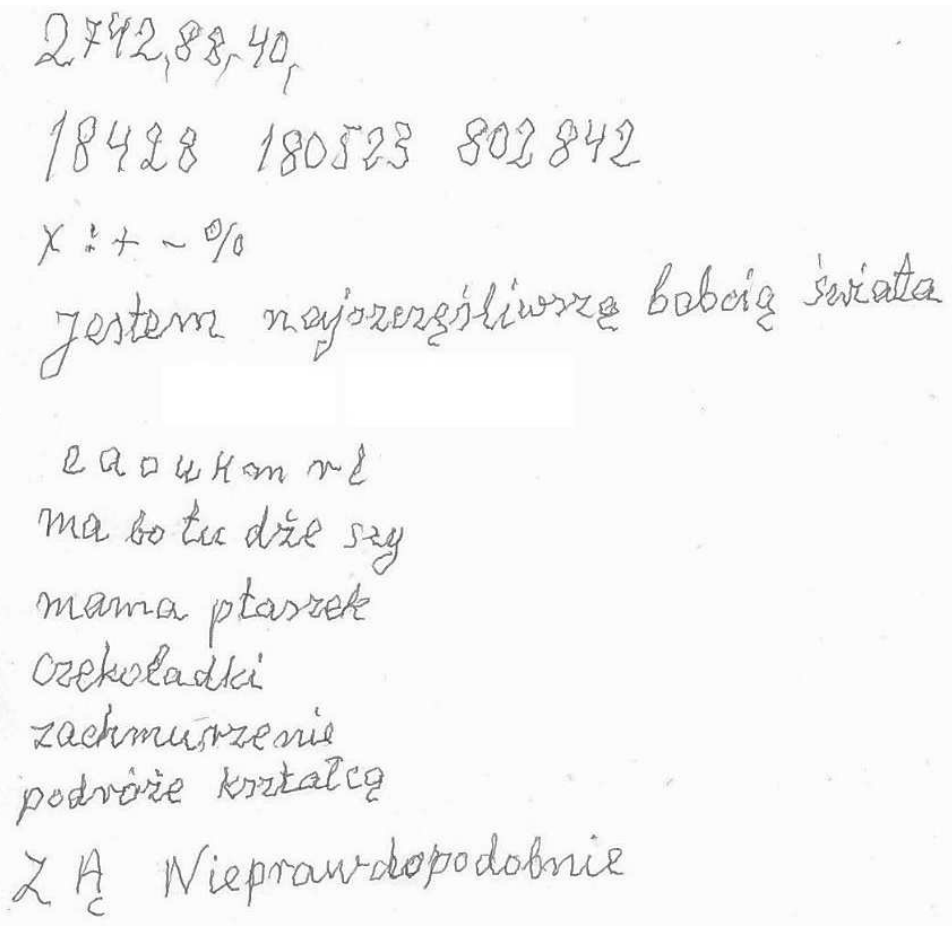

Rys. 1. Próbka pisma chorej (źródło: zbiory własne)

\section{Terapia logopedyczna}

W wyniku postawionej diagnozy logopedycznej kolejnym etapem jest wdrożenie planu terapeutycznego. U pacjentki można zaobserwować podstawowe zaburzenia mowy w chorobie Parkinsona wskazywane $w$ literaturze. $W$ związku $z$ tym terapia mowy powinna dotyczyć przede wszystkim rehabilitacji głosu, regulacji oddechu, poprawy fonacji oraz sprawności narządów artykulacyjnych. Usprawnienie ruchomości artykulatorów, siły mięśni krtani, oddychania, fonacji, prozodii, głośności mowy i precyzji artykulacyjnej przyczyni się do poprawy jakości mowy i jej zrozumienia. Nasilające się problemy z połykaniem także powinny zostać uwzględnione 
podczas tworzenia programu terapeutycznego. Ćwiczenia logopedyczne należałoby wykonywać systematycznie przez długi okres tylko takie postępowanie może przynieść jakiekolwiek rezultaty.

Dotychczasowa terapia pacjentki trwała cztery miesiące, nie przynosząc oczekiwanych rezultatów. Sesja terapeutyczna odbywała się dwa razy w tygodniu i trwała 45 minut. Dodatkowo pacjentka każdego dnia samodzielnie wykonywała zalecone ćwiczenia. W planie terapeutycznym znalazły się ćwiczenia: prawidłowego połykania, oddechowe, usprawniające pracę narządów artykulacyjnych, fonacyjne, artykulacyjne oraz prozodii mowy. Dokładnego ich opisu dokonano poniżej.

\section{Ćwiczenia prawidłowego połykania}

Dysfagia jest częstym zaburzeniem w chorobie Parkinsona. Polega ona na niemożności prawidłowego przełykania pokarmów i nasila się wraz z czasem trwania choroby. Nie zależy ona od wie$\mathrm{ku}$ pacjenta. $\mathrm{W}$ ostatnim stadium choroby Parkinsona leczenie farmakologiczne dysfagii nie przynosi rezultatów, ponieważ proces neurodegradacji i niszczenie neuronów są nasilone. Pojawia się dodatkowo ślinotok, który jest wynikiem zaburzonych ruchów połykania. Przyczynia się to do zwiększenia ryzyka zachłyśnięcia przez chorego. W tym wypadku należy włączyć ćwiczenia rehabilitacyjne dla chorych z dysfagią oraz bezwzględnie przestrzegać zasad bezpiecznego spożywania posiłków ${ }^{15}$.

Chora ma wszystkie objawy opisane powyżej. W związku z tym wdrożono do terapii ćwiczenia polegające na unoszeniu przedniej i tylnej części języka przy otwartych ustach, wstrzymaniu oddechu na 5 sekund i powtarzaniu samogłoski $a$, wykonywaniu manewru Mendelsona, zastosowaniu wspomagających technik połykania, tj. pochylenie głowy w celu ułatwienia przejścia pokarmu do przeły-

15 A. Potulska-Chromik, Zaburzenia potykania w chorobie Parkinsona, [w:] Mam chorobę Parkinsona. Poradnik dla chorych i ich rodzin, red. J. Sławek, Wydawnictwo Via Medica, Gdańsk 2010, s. 72. 
$\mathrm{ku}^{16}$. Chora otrzymała także wskazówki dotyczące bezpiecznego spożywania posiłków. W trakcie trwania terapii przestrzegała wszystkich zasad. Z wywiadu wynikało, że dolegliwości nieznacznie się wycofały.

\section{Ćwiczenia oddechowe}

Stanowią one bardzo ważny wstęp do właściwej terapii mowy. Możemy je wykonywać jednocześnie z ćwiczeniami relaksacyjnymi. Prawidłowe oddychanie jest niezwykle ważne, ponieważ warunkuje ono silny głos i dobrą wymowę. Ćwiczenia oddechowe w chorobie Parkinsona mają głównie na celu wydłużenie fazy wydechowej, a także powiększenie pojemności życiowej płuc, skorygowanie nieprawidłowego toru oddechowego, ułatwienie kontroli nad oddechem oraz poprawę koordynacji i napięcia mięśni oddechowych ${ }^{17}$

Pacjentce zaproponowano ćwiczenie relaksacyjne - wygodnie siedzenie na fotelu z zamkniętymi oczami i spokojne pobieranie powietrza nosem i wydychanie ustami (powietrze "przemieszcza się" od ust aż do stóp). Wśród ćwiczeń oddechowych znalazły się m.in. dmuchanie przez słomkę do szklanki z wodą, zabawy z dmuchajką polegające na utrzymaniu piłeczki w powietrzu poprzez dostarczanie powietrza przez słomkę, liczenie na wydechu, ziewanie przy opuszczonej żuchwie (język spoczywa w jamie ustnej) oraz wydech naśladujący chrapanie. Wszystkie z powyższych ćwiczeń pacjentka wykonywała poprawnie.

\section{Ćwiczenia usprawniające pracę narządów artykulacyjnych}

Ćwiczenia wykonywane z chorą miały na celu zmniejszenie podwyższonego napięcia mięśni twarzy (odpowiedzialnych za mi-

16 Ibidem.

17 T. Lewicka, Diagnoza i terapia zaburzeń mowy pacjentów z choroba Parkinsona, „Logopeda” 2009, nr 1(7), s. 121. 
mikę) oraz polepszenie sprawności narządów artykulacyjnych w szczególności mięśni języka, policzków i warg, które są odpowiedzialne za wyraźną mowę. Na ćwiczenia składało się m.in.: wysuwanie do przodu zaokrąglonych warg (robienie dziubka), wymawianie samogłosek $a, o, u, e \mathrm{w}$ hiperpoprawny sposób, zakładanie górnej wargi na dolną i odwrotnie, przygryzanie górnej wargi dolnymi zębami i odwrotnie, szerokie uśmiechy, wykonywanie na przemian dziubka i uśmiechu. Pacjentka ćwiczyła także wypychanie policzków powietrzem i przenoszenie go z prawego do lewego policzka, unoszenie czubka języka do wałka dziąsłowego za górnymi zębami, szybkie wysuwanie i chowanie języka do jamy ustnej, oblizywanie warg językiem, wykonywanie śmiesznych min i przesuwanie języka do kącików ust.

Ćwiczenia narządów artykulacyjnych były dla pacjentki męczące. Szybko zniechęcała się, niekiedy odczuwając ból. W takiej sytuacji zawsze przerywano ćwiczenia w celu uniknięcia dodatkowych urazów.

\section{Ćwiczenia fonacyjne}

Sztywność mięśni oraz hipokineza krtani w chorobie Parkinsona przyczyniają się do znacznego obniżenia jakości głosu. Staje się on monotonny, przypomina szept w przebiegu zapalenia krtani, a jego modulacja jest ograniczona. W związku z tym chory nie może uzyskać prawidłowej fonacji. Celem ćwiczeń fonacyjnych jest zatem skoordynowanie prawidłowego oddechu $\mathrm{z}$ fonacją, ustawienie głosu na odpowiednim poziomie, kontrola jego wysokości, ustalenie natężenia głosu oraz osiągnięcie prawidłowego rezonansu i prozodii 18 .

Pacjentce zaproponowano następujące ćwiczenia: unoszenie zaciśniętych dłoni na wysokości klatki piersiowej oraz energiczne opuszczenie ich w dół z jednoczesną emisją głosek $a, o, i, u$, fonowa-

18 T. Lewicka, A. Rodzeń, Ćwiczenia rehabilitacyjno-logopedyczne dla osób z choroba Parkinsona, Wydawnictwo Roche Polska, Warszawa 2013, s. 23. 
nie samogłosek $a, o, e, o, u, y$, wykonywanie tzw. murmuranda na głosce $m$, podnoszenie i obniżanie głośności podczas wypowiadania dowolnych ciągów wyrazowych, samogłosek itp., wypowiadanie silnym głosem dźwięku ach!.

\section{Ćwiczenia artykulacyjne}

Zaburzenia artykulacji $\mathrm{w}$ chorobie Parkinsona pojawiają się stopniowo. W końcowej fazie znacznie utrudniają one mówienie. Chory zaczyna z czasem niewyraźnie wypowiadać zarówno samogłoski, jak i spółgłoski. Nieprawidłowo wymawiane są najczęściej głoski $f$ i $w$ (tj. wargowo-zębowe) oraz $p, b, m$ (dwuwargowe). Przyczyną znacznych zniekształceń artykulacji przytoczonych spółgłosek jest wzmożone napięcie mięśniowe warg i języka ${ }^{19}$. Głównym celem ćwiczeń artykulacyjnych jest poprawa wyrazistości mowy.

Wśród ćwiczeń zaproponowanych pacjentce znalazło się wypowiadanie jednosylabowych i wielosylabowych wyrazów oraz zdań prostych i złożonych, a także czytanie tekstów na głos. Wszystkie ćwiczenia były wykonywane $\mathrm{z}$ hiperpoprawną wymową każdej głoski i wyraźną mimiką ust.

\section{Ćwiczenia prozodii mowy}

Choroba Parkinsona wpływa także niekorzystnie na melodyjność i intonację wypowiedzi. W związku z tym pacjentce polecono wykonywanie ćwiczeń interpretacyjnych (aktorskich) - m.in. odczytywanie tekstu z określonym nacechowaniem uczuciowym, a także odczytywanie wierszy z odpowiednią intonacją, wyrażanie uczuć $\mathrm{z}$ odpowiednią intonacją, zadawanie pytań oraz wypowiadanie wykrzyknień.

${ }^{19}$ K. Gawęda, J. Łazewski, op. cit., s. 68. 


\section{Wnioski}

Zaburzenia mowy u pacjentki polegają przede wszystkim na zmianie barwy głosu i nieprawidłowej fonacji. Głos jest ochrypły i cichy, a tempo mówienia uległo zwolnieniu. Płynność mowy zaburzają liczne pauzy występujące $w$ mowie spontanicznej. Prozodia i rytm są nieprawidłowe - mowa staje się coraz bardziej monotonna. Precyzja artykulacyjna także uległa pogorszeniu - dostrzec można tzw. "zamazanie” artykulacji. Sprawność narządów artykulacyjnych również się obniżyła. Objawy zaburzeń mowy spowodowane są nieprawidłowym ruchem strun głosowych, zmęczeniem, podwyższonym napięciem mięśni krtani oraz osłabieniem ich aktywności, a także wzmożeniem napięcia mięśniowego twarzy. W pełni odpowiadają one symptomom opisanym w literaturze dotyczącej mowy w chorobie Parkinsona ${ }^{20}$. Pozostałe obszary, które zostały poddane badaniu pozostają $\mathrm{w}$ normie. Pacjentka nie ma problemu z rozumieniem mowy, jednak coraz częściej trudność sprawia jej produkowanie mowy.

Choroba Parkinsona jest specyficznym schorzeniem, które u każdego pacjenta przebiega w inny sposób. Zaprezentowany przypadek może stanowić egzemplifikację postępowania terapeutycznego dla innych logopedów, ułatwiającą pracę z osobami z tego typu zaburzeniami mowy i komunikacji. Choć w zaawansowanym stadium choroby terapia logopedyczna nie przynosi już efektów, nie należy zaprzestać oddziaływań logopedycznych. Systematyczne ćwiczenia mogą podtrzymywać zaburzone funkcje i powodować opóźnienie progresji schorzenia. Choroba Parkinsona jest schorzeniem postępującym, w związku z tym zadaniem terapeuty mowy jest zahamowanie jej rozwoju i niedopuszczenie do całkowitej utraty mowy. Nigdy nie powinno się zostawiać pacjenta bez opieki logopedycznej, nawet jeśli znajduje się już w ostatnim stadium choro-

20 A. Potulska-Chromik, Zaburzenia mowy w chorobie Parkinsona, [w:] Mam chorobę Parkinsona. Poradnik dla chorych $i$ ich rodzin, red. J. Sławek, Wydawnictwo Via Medica, Gdańsk 2010, s. 73-74. 
by. Każde dodatkowe działanie bowiem przyczynia się do wydłużenia czasu, w którym pacjent może posługiwać się mową i porozumiewać dzięki temu z otoczeniem drogą werbalną.

\section{Bibliografia}

Gajos A., Co to jest choroba Parkinsona, jak często wystepuje I jakie sa kryteria rozpoznania?, [w:] Mam chorobę Parkinsona. Poradnik dla chorych $i$ ich rodzin, red. J. Sławek, Wydawnictwo Via Medica, Gdańsk 2010.

Gawęda K., Łazewski J., Rehabilitacja mowy w chorobie Parkinsona, Wydawnictwo Mada, Warszawa 2012.

Janik P., Przebieg choroby i jej rokowanie, [w:] Mam chorobę Parkinsona. Poradnik dla chorych $i$ ich rodzin, red. J. Sławek, Wydawnictwo Via Medica, Gdańsk 2010.

Jauer-Niworowska O., Zaburzenia mowy u osób z chorobą Parkinsona - nie tylko dyzartria. Złożoność uwarunkowań trudności w komunikacji werbalnej, Wydział Polonistyki Uniwersytetu Warszawskiego, Warszawa 2016.

Kuran W., Żyje z choroba Parkinsona, Wydawnictwo Lekarskie PZWL, Warszawa 2002.

Lewicka T., Diagnoza $i$ terapia zaburzeń mowy pacjentów z choroba Parkinsona, „Logopeda” 2009, nr 1(7).

Lewicka T., Rodzeń A., Ćwiczenia rehabilitacyjno-logopedyczne dla osób z choroba Parkinsona, Wydawnictwo Roche Polska, Warszawa 2013.

Mccall B., Jak radzić sobie z chorobą Parkinsona?, Wydawnictwo Feeria, Łódź 2007.

Petit H., Allain H., Vermersch P., Choroba Parkinsona. Klinika i leczenie, Wydawnictwo Medyczne Sanmedica, Warszawa 1997.

Potulska-Chromik A., Zaburzenia mowy w chorobie Parkinsona, [w:] Mam chorobę Parkinsona. Poradnik dla chorych i ich rodzin, red. J. Sławek, Wydawnictwo Via Medica, Gdańsk 2010.

Potulska-Chromik A., Zaburzenia potykania w chorobie Parkinsona, [w:] Mam chorobe Parkinsona. Poradnik dla chorych $i$ ich rodzin, red. J. Sławek, Wydawnictwo Via Medica, Gdańsk 2010.

Rudzińska M., Gatkowska I., Mirek E., Szczudlik A., Choroba Parkinsona. Poradnik dla pacjentów $i$ ich rodzin, Wydawnictwo Uniwersytetu Jagiellońskiego, Kraków 2009.

Szłapa K., Tomasik I., Wrzesiński S., Kwestionariusz diagnostyczny zaburzeń mowy ze szczególnym uwzględnieniem afazji i dysartrii dla młodzieży i dorostych, Wydawnictwo Harmonia, Gdańsk 2014. 